\title{
Review
}

Yolanda Freile-Pelegrín* and Deniz Tasdemir

\section{Seaweeds to the rescue of forgotten diseases: a review}

https://doi.org/10.1515/bot-2018-0071

Received 15 July, 2018; accepted 18 January, 2019; online first 5 March, 2019

Abstract: Neglected tropical diseases (NTDs) are a group of diseases that are predominant in the poorest parts of the world affecting 1.4 billion people. The development of new drugs is urgently needed in order to combat these forgotten diseases. Natural products from marine organisms have been widely explored as a source of new bioactive molecules. However, despite their enormous potential in drug discovery, not even one seaweed-based molecule has entered pre-clinical testing for NTDs. This review gives an overview of the current status of algal natural products against NTDs. The list of compounds is by no means exhaustive, but covers the most important classes of active substances in marine algae against the most studied NTDs.

Keywords: insect-borne infections; leishmaniasis; neglected tropical diseases; seaweed; trypanosomiasis.

\section{Introduction}

Forgotten diseases refer to those that rarely reach the attention of people who live in the wealth and abundance of the developed world. Neglected Tropical Diseases (NTDs), a group of parasitic, bacterial, viral and fungal infections, are among the most common causes of illness of the poorest people living in developing countries (Hotez et al. 2007). These diseases prevail in tropical and sub-tropical conditions in as many as 149 countries around the globe where the affected individuals are often afflicted with more than one parasite or infection. NTDs

*Corresponding author: Yolanda Freile-Pelegrín, Department of Marine Resources, Cinvestav-Unidad Merida, 97310, A.P.73 Cordemex, Merida, Yucatan, Mexico, e-mail: yolanda.freile@cinvestav.mx Deniz Tasdemir: GEOMAR Centre for Marine Biotechnology (GEOMAR-Biotech), Marine Natural Products Chemistry Research Unit, GEOMAR Helmholtz Centre for Ocean Research Kiel, Am Kiel Kanal 44, 24106 Kiel, Germany; and Kiel University, ChristianAlbrechts-Platz 4, Kiel 24118, Germany include, among others, leishmaniasis, Chagas' disease and Dengue fever, affecting approximately 1.4 billion people, and they cost developing economies billions of dollars every year. It has been estimated that these diseases worldwide cause 35,000 deaths daily (Cohen et al. 2016). Sadly, NTDs are over-shadowed by the three important diseases, human immunodeficiency virus (HIV), tuberculosis and malaria, which generally receive more funding for research. However, co-infection by NTDs can also make those diseases fatal. Consequently, NTDs were also taken into account and incorporated into the Global Fund to Fight HIV, tuberculosis, and malaria (Hotez 2013).

NTDs are not only confined to those areas of the world which are traditionally considered to be developing nations but, according to Hotez (2010, 2017), American populations, living in poverty, also suffer from NTD-like infections. Parasitic diseases have been reported to occur with high frequency, post-hurricane Katrina, in Louisiana and other parts of the Mississippi Delta. However, their importance has been under-estimated since many are asymptomatic and have long incubation periods, and the connection between a death and a specific NTD that has lain latent for a long period of time is not often realized. On the other hand, current political destabilizations in different areas have led to outbreaks of cutaneous and visceral leishmaniasis that have collapsed the infrastructure of the health system in Syria, Iraq, Afghanistan, Sudan and South Sudan, while in Venezuela, malaria, Chagas' disease, schistosomiasis, dengue and other arthropod-borne virus infections have also resurfaced.

To date, the World Health Organization (WHO) has recognized 18 NTDs, which have treatment possibilities with a high probability of being effectively controlled (WHO 2017). Table 1 summarizes these 18 NTDs classified by the causative agent, and lists their clinical manifestations as well as current market treatments, including also those undergoing clinical trials. A reason suggested for the neglect of these diseases is that they are not commercially attractive and consequently, patents and profit play no role in stimulating innovation. Currently, the large multibillion dollar pharmaceutical industry views research and development as highly risky, since the development of new 
Table 1: Neglected tropical diseases (NTD) registered by World Health Organization: classification, definition, and current market and clinical trials treatments.

\begin{tabular}{|c|c|c|c|}
\hline NTD & Causative agent and clinical manifestations & Current treatment & References \\
\hline \multicolumn{4}{|l|}{ Bacterial infections } \\
\hline Buruli ulcer & $\begin{array}{l}\text { Mycobacterium ulcerans. A debilitating } \\
\text { mycobacterial infection causing severe } \\
\text { destruction of the skin, bone and soft tissue }\end{array}$ & Rifampicin + Streptomycin; Amikacin & $(1,2,3)$ \\
\hline $\begin{array}{l}\text { Leprosy } \\
\text { (Hansen's } \\
\text { disease) }\end{array}$ & $\begin{array}{l}\text { Mycobacterium leprae. A complex disease caused } \\
\text { by infection of the skin, peripheral nerves, } \\
\text { mucosa of the upper respiratory tract and eyes. } \\
\text { Leprosy is curable and treatment provided in the } \\
\text { early stages averts disability }\end{array}$ & $\begin{array}{l}\text { Rifampicin + Clofazimine + Dapsone; } \\
\text { Rifampicin + Dapsone; } \\
\text { Rifampicin + Ofloxacine + Minocycline; } \\
\text { Rifampicin + Clofazimine + Dapsone } 2 \\
\text { (phase IV) }\end{array}$ & $(1,2,3,4)$ \\
\hline Trachoma & $\begin{array}{l}\text { Chlamydia trachomatis. Transmitted through } \\
\text { direct contact with infectious eyes or nasal } \\
\text { discharge. Causes irreversible corneal opacity } \\
\text { and blindness }\end{array}$ & $\begin{array}{l}\text { Azithromycin; Tetracycline; Doxycycline } \\
\text { (phase III) }\end{array}$ & $(1,2,4)$ \\
\hline Yaws March & $\begin{array}{l}\text { Treponema pallidum. A chronic bacterial } \\
\text { infection affecting mainly the skin and bones }\end{array}$ & Azithromycin; Benthacine; Penicillin & $(1,2,3)$ \\
\hline \multicolumn{4}{|l|}{ Viral infections } \\
\hline Rabies & $\begin{array}{l}\text { Rabies virus (genus: Lyssavirus). A preventable } \\
\text { disease transmitted through the bites of infected } \\
\text { dogs that is fatal once symptoms develop }\end{array}$ & Cell cultured-based vaccines & $(1,2)$ \\
\hline $\begin{array}{l}\text { Dengue, } \\
\text { Zika and } \\
\text { Chikungunya }\end{array}$ & $\begin{array}{l}\text { Dengue and Zika viruses (genus: Flavivirus); } \\
\text { Chikungunya virus (fam. Togaviridae). Mosquito- } \\
\text { borne infections causing a self-limiting acute } \\
\text { febrile illness with headache, myalgia and rash }\end{array}$ & $\begin{array}{l}\text { No specific drugs; Nucleoside inhibitor for } \\
\text { dengue fever (phase I); Live attenuated } \\
\text { tetravalent dengue vaccine vaccine } \\
\text { (Dengvaxia }(\text { ) }\end{array}$ & $(1,5,6)$ \\
\hline \multicolumn{4}{|l|}{ Fungal infections } \\
\hline Mycetoma & $\begin{array}{l}\text { Various fungi (eumycetoma) and bacteria } \\
\text { (actinomycetoma, pseudomycetoma). } \\
\text { A chronic, destructive inflammatory skin disease } \\
\text { caused by inoculation through skin damage of } \\
\text { fungi or bacteria into the subcutaneous tissue }\end{array}$ & $\begin{array}{l}\text { There are no specific treatments. Patients are } \\
\text { treated with ketoconazole or itraconazole. } \\
\text { As a second line treatment, voriconazole and } \\
\text { posaconazole are also used }\end{array}$ & (7) \\
\hline \multicolumn{4}{|l|}{ Protozoal infections } \\
\hline $\begin{array}{l}\text { Human African } \\
\text { Trypanosomiasis } \\
\text { (sleeping } \\
\text { sickness) }\end{array}$ & $\begin{array}{l}\text { Trypanosoma brucei gambiense; T. brucei } \\
\text { rhodesiense. A vector-borne parasitic disease } \\
\text { transmitted by tsetse fly (Glossina spp.) bites } \\
\text { which have acquired their infection from human } \\
\text { beings or from animals harboring human } \\
\text { pathogenic parasites. Initially, there are fevers, } \\
\text { headaches, itchiness and joint pains. The second } \\
\text { stage begins with confusion, poor coordination, } \\
\text { numbness and trouble sleeping. It is almost } \\
100 \% \text { fatal without prompt diagnosis and } \\
\text { treatment }\end{array}$ & $\begin{array}{l}\text { Nifurtimox + Eflornithine; Pentamidine; } \\
\text { Suramin; Melarsoprol; Eflornithine; } \\
\text { Fexinidazole (phase III); Oxaborole SCYX-7158 } \\
\text { (phase III) }\end{array}$ & $(1,4,5)$ \\
\hline Chagas disease & $\begin{array}{l}\text { Trypanosoma cruzi. A life-threatening illness } \\
\text { transmitted through contact with vector insects } \\
\text { (triatomine bugs), ingestion of contaminated } \\
\text { food, infected blood transfusions, congenital } \\
\text { transmission or organ transplantation }\end{array}$ & $\begin{array}{l}\text { Benznidazole; Nifurtimox; } \\
\text { benznidazole + fosravuconazole (phase II) }\end{array}$ & $(1,4,5)$ \\
\hline Leishmaniasis & $\begin{array}{l}\text { Leishmania donovani; L. chagasi; L. infantum; } \\
\text { L. major; L. tropica: L. braziliensis; L. mexicana } \\
\text { and other Leishmania spp. Transmitted by the } \\
\text { bites of infected female phlebotomine sandflies. } \\
\text { There are three forms of the disease: visceral (the } \\
\text { most serious form of the disease characterized by } \\
\text { irregular bouts of fever, weight loss, enlargement } \\
\text { of the spleen and liver, and anemia), cutaneous } \\
\text { and mucocutaneous }\end{array}$ & $\begin{array}{l}\text { Liposomal amphotericin B; } \\
\text { Paromomycin; Miltefosine; Sodium } \\
\text { stibogluconate + Paromomycin; Pentavalent } \\
\text { antimonials; AmBisome; Deoxycholate Gilead; } \\
\text { Deoxycholate; AmBisome + Miltefosine; } \\
\text { AmBisome + Paromomycin; } \\
\text { Miltefosine + Paromomycin }\end{array}$ & $(1,4,5)$ \\
\hline
\end{tabular}


Table 1 (continued)

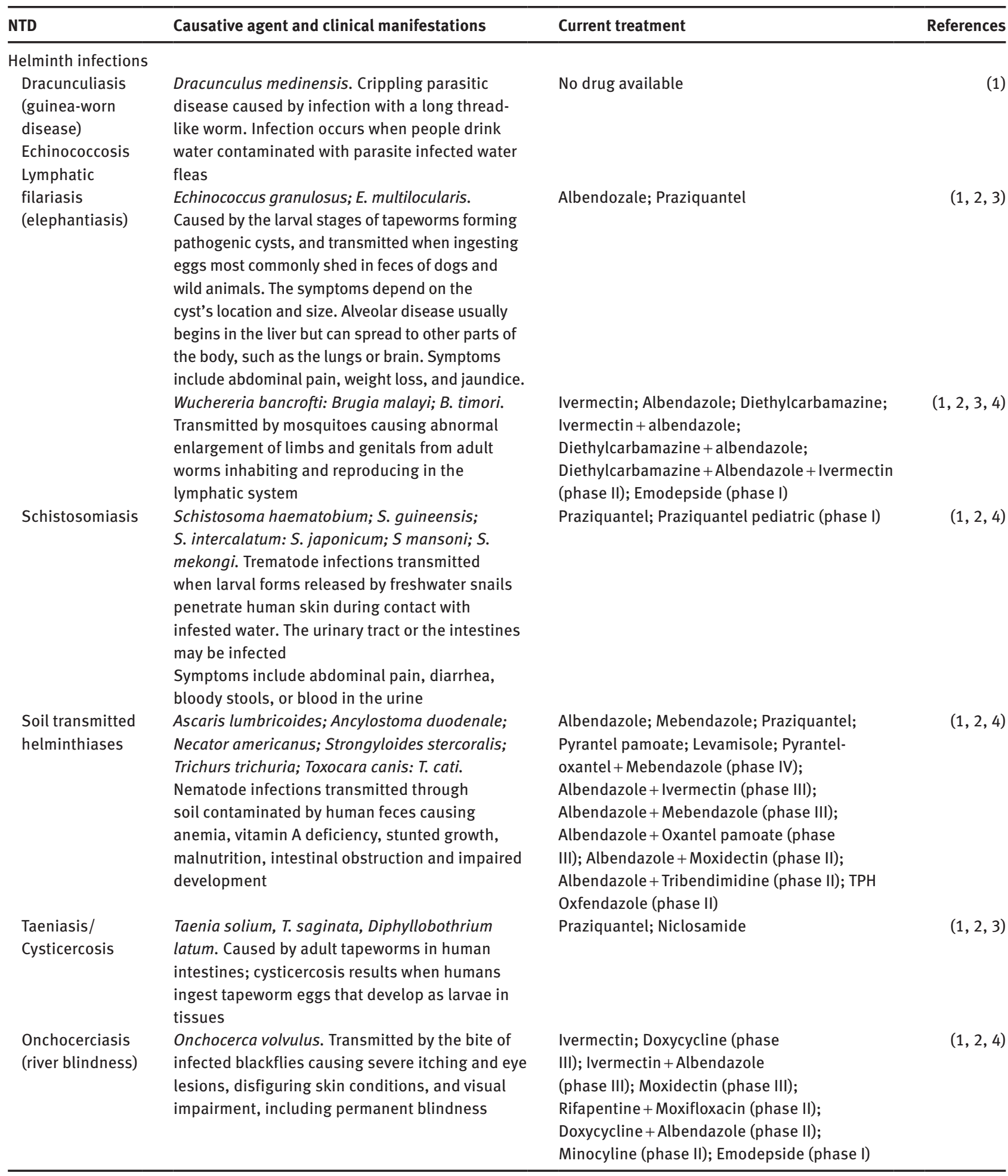

References: (1) WHO 2017; (2) Utzinger et al. 2012; (3) di Procolo and Jommi 2014; (4) BVGH 2015; (5) Hotez et al. 2016; (6) Scott 2016; (7) Weish et al. 2014.

drugs is a long, difficult and expensive process, and only $0.02 \%$ of tested compounds actually manage to be treated with license. Thus, while preclinical testing analyzes in vitro and in vivo bioactivity, safety and efficacy of the new proposed drugs, clinical research necessitates trials done in humans. These trials incorporate a number of sequential 
steps or phases. A potential new medicine may be rejected at any point in the development process and, overall, it may take 10-15 years before it reaches the patients. For this reason, resources are not put into the field of NTDs treatments and new chemical entities are often expensive: Trouiller et al. (2002) reported that only 13 of the 41,400 new molecular entities approved world-wide between 1975 and 1999 targeted NTDs. In a more recent review, Pedrique et al. (2013) described 850 new therapeutic products that were approved between 2000 and 2011. Of these, only 37 (4\%) were against NTDs, comprising 25 products with a new indication or formulation and 8 vaccines. Only 4 new chemical entities were approved for NTDs (three for malaria, one for diarrheal disease), accounting for $1 \%$ of the 336 new chemical entities approved during the study period and, of about 150,000 clinical trials registered in late 2011, only $2016(1 \%)$ are for NTDs. Therefore, the need to investigate new therapies, drugs and vaccines for these diseases is very clear and different initiatives were carried out. In 2003, a collaborative drug research and development organization (Drugs for Neglected Diseases Initiative) was established. Efforts to combat the NTDs reached a turning point in 2007, when WHO convened the first meeting of global partners and, in 2012, published "A Roadmap for Implementation" with the aim to accelerate the control and elimination of NTDs. Inspired by WHO's Roadmap, the "London Declaration on NTDs" was also written and endorsed by a number of organizations and pharmaceutical companies. Together, they committed "to control, eliminate or eradicate” 10 NTDs by 2020 (WHO 2017).

Marine natural products have been widely explored as a source of new drug candidates since sessile organisms such as sponges, bryozoans and tunicates produce numerous secondary metabolites with wide ranging biological activities. Examining Table 1, it is disappointing to note that no natural (marine) products or their derivatives have entered pre-clinical testing for NTDs.

Among marine organisms, macroalgae (seaweeds) have proven to be a prolific source of various types of secondary metabolites with complex and unique chemical structures, and with a wide spectrum of potential biological activities. These include effects such as antibacterial, anti-fungal, anti-protozoal, anti-tuberculosis, anti-coagulant, anti-thrombotic and anti-viral (VonthronSénécheau 2016). Despite the enormous potential of seaweeds in drug discovery, no natural products from algae or their derivatives have entered the pre-clinical testing for NTDs (Falkenberg et al. 2018). In this review, we address the research conducted on seaweed-derived molecules and their impact against the main and most studied NTDs.
This review is limited only to reported activities that have been associated with a particular known compound or, at a minimum, with a broad group of compounds.

\section{Major bioactive metabolites from seaweeds}

Seaweeds were considered to be of medicinal value as early as 3000 B.C. in Asian cultures. The Romans and some British populations also used them for over a 1000 years for healing wounds and as efficient vermifuges or anthelmintics (Smit 2004). Nowadays, the search for treatments of human diseases appears to be a continuous process. Numerous algal species, including Rhodophyta, Phaeophyceae and Chlorophyta, have the capacity to produce a diverse array of secondary metabolites with important roles around chemical defenses. Excellent reviews concerning bioactive metabolites from seaweeds have been published recently which estimate that more than 3000 natural compounds with pharmacological properties have been discovered in the last five decades, many of them reported as novel compounds with unique chemical structures (Smit 2004, Pereira and Costa-Lotufo 2012, Blunt et al. 2013). Although terpenes and halogenated compounds have received the most attention, mainly due to their strong bioactivities, other bioactive components also include sulfated polysaccharides (SPs), polyphenols, proteins, peptides, amino acids, and lipids. The bioactivity of these various compounds in seaweeds is briefly discussed below:

(a) Terpenes and halogenated compounds: In seaweeds, terpenes represent one of the major classes of metabolites, some of which are reported as potent drugs against cancer, malaria and heart diseases, some with insecticidal properties (Al-Massarani 2014, Yu et al. 2014, Chen et al. 2018). Chemically, they are classified according to the number of isoprene units into monoterpenes ( 2 isoprene units, C10), sesquiterpenes (3 isoprene units, C15), diterpenes ( 4 isoprene units C20), triterpenes (6 isoprene units $\mathrm{C} 30$ ) and polyterpenes (>C30). Species of Chlorophyta contain cyclic and linear sesqui-, di-, and triterpenes, while red algae are characterized by a high structural diversity of polyhalogenated terpenes, which exhibit a wide range of biological activities. The various antibacterial, antifungal, antiviral, anti-inflammatory, antiproliferative, antifouling, cytotoxic, ichthyotoxic, and insecticidal activity associated with halogenated seaweed metabolites have been well documented. 
Chlorine and bromine atoms appear particularly to increase biological activity (Blunt et al. 2009, Cabrita et al. 2010). Species belonging to the genera Laurencia (Al-Massarani 2014, Souza de Oliveira et al. 2015) and Asparagopsis (Máximo et al. 2018) are prolific producers of chlorinated and/or brominated sesquiterpenoids. Elatol, an halogenated sesquiterpene, is one of them with pharmacological potential due to its strong biological activities (Souza de Oliveira et al. 2015 and references therein). Halomon, a pentahalogenated monoterpene originally isolated in 1975 from Portieria hornemannii (Lyngbye) P.C. Silva (Gigartinales) was found to have a strong cytotoxicity against brain, renal and colon tumor cell-lines (Fuller et al. 1992). This compound was selected for further preclinical studies, but problems with biomass supply and bioavailability hampered further trials. Consequently, synthetic methods for the preparation of halomon and related compounds were successfully developed (Bucher et al. 2015). The red alga Plocamium cornutum yields halogenated monoterpenes with antiplasmodial activity against the chloroquine sensitive strain of Plasmodium falciparum (Afolayan et al. 2009). Bromophycolides from Callophycus serratus also exhibited antimalarial activity against $P$. falciparum (Lane et al. 2009).

(b) Sulfated polysaccharides: Seaweeds contain large amounts of cell wall polysaccharides whose biological function is to provide a flexible structure that helps them resist currents and movement of the waves. These heterogeneous and complex polymers are of high commercial interest as phycocolloids in the food industry and in the biomedical field. Seaweed polysaccharides contain neutral sugars and sugar acids as constituents, but some also contain sulfate groups attached to the hydroxyl groups of sugars. The sulfated polysaccharides are of taxonomic importance: agar and carrageenans (sulfated galactans) are common in Rhodophyta; ulvans are common in Chlorophyta, while fucoidan (sulfated L-fucose) is common in brown seaweeds (order Fucales). The sulfated polysaccharides do not occur in terrestrial plants and are defined as bioactive polysaccharides with different biological activities. Carrageenans and fucoidan are among the most studied compounds with numerous activities, such as antioxidant, antitumor, anticoagulant, anti-inflammatory and antiviral (Zhou et al. 2005, Jiao et al. 2011, Dai-Hung and Se-Kwon 2013, Cunha and Grenha 2016). The diverse structural types of carrageenans have shown antiviral activity against enveloped viruses. For example, Carlucci et al. (1999) reported potent antiviral effects against Herpes simplex virus type 1 (oral herpes) and type 2 (genital herpes) of $\lambda$-carrageenan obtained from Gigartina skottsbergii. Talarico et al. (2004) found that $\mathrm{v} / \mathrm{k} / \mathrm{v}$ carrageenans and DL-galactan hybrids from Gymnogongrus griffithsiae and Cryptonemia crenulata also showed activity against these viruses. Fucoidans have also shown a potent antiviral activity against numerous enveloped viruses including $H$. simplex virus type 1 (Hayashi et al. 2008). Many biological effects of the sulfated polysaccharides are related to their ability to change the surface properties of the cell that inhibit target cell binding and thus prevent the entry of the virus (Chen et al. 1997). Extensive research on fucoidans has shown other beneficial pharmacological effects in vitro and in vivo, such as anti-inflammatory, antioxidant and hepatoprotective activities and as possible anticancer agents (Ananthi et al. 2010, Vasquez et al. 2012, Chale-Dzul et al. 2015, Lowenthal and Fitton 2015).

(c) Polyphenols and phlorotannins: Polyphenols consist of a hydroxyl group $(\mathrm{OH})$ directly bonded to an aromatic hydrocarbon group. They can donate hydrogen to free radicals and convert them into non-reactive radicals; therefore, they are strong antioxidants. Phlorotannins in seaweeds are polyphenols formed by polymerization of phloroglucinol through the acetate-malonate pathway and are restricted to brown marine algae (Ragan and Glombitza 1986).

(d) Amino acid derivatives: Algal proteinaceous molecules include proteins, peptides, amino acids, and amino acid-like components, which have shown potent biological activities (Harnedy and FitzGerald 2011, Samarakoon and Jeon 2012). Seaweeds have been recognized as excellent reservoirs of proteins (up to $47 \%$ ) that are present in diverse forms and locations such as enzymes, constituents of the cell wall, and bound to pigments and carbohydrates (Fleurence 2004). Within algal proteins, lectins and phycobiliproteins have shown a wide range of bioactivities. Lectins are carbohydrate-binding proteins that are involved in host-pathogen interactions, cell-cell communication or induction of apoptosis (Huskens and Schols 2012). Phycobiliproteins are water-soluble pigmentprotein complexes, highly fluorescent and brilliantly colored due to the presence of covalently attached prosthetic groups, bilins, which are linear tetrapyrroles (Glazer 1994). They are found in red seaweeds and, as pigments, phycobiliproteins are involved in light-harvesting and photoprotection since they are able to quench singlet oxygen and scavenge free radicals. Therefore, most data concerning their bioactivity 
is related to their antioxidant capacity in the prevention of many pathological conditions caused by oxidative stress (Stadnichuk and Tropin 2017). Other important photoprotective mechanisms in seaweeds include the synthesis of mycosporine-like amino acids (MAAs). MAAs are water soluble, low-molecular weight compounds that are composed of either an aminocyclohexenone or an aminocycloheximine ring conjugated with one or more amino acid residues. They protect aquatic organisms against UV radiation (Karsten et al. 1998), hence they are of pharmaceutical interest for their robust antioxidative properties (Hartmann et al. 2015). Marine peptides, consisting of linear and cyclic peptides with one or more amide bonds replaced by an ester bond, have opened up a new way to develop pharmaceutical agents and have shown antimicrobial, antifungal, antimalarial, antiprotozoal, antituberculosis, and antiviral activities (Kim and Wijesekara 2010, Kang et al. 2015). The most remarkable is the cyclic depsipeptide kahalide $F$ obtained from the herbivorous marine mollusks Elysia rufescens, Elysia ornata or Elysia grandifolia and their algal diet, the chlorophyte Bryopsis pennata and Bryopsis plumosa (Hamann et al. 1996). Most seaweeds contain essential amino acids. They are a rich source of aspartic and glutamic acid (Fleurence 2004) and some red seaweeds contain unusual amino acids e.g. taurine ( $\beta$-alanine sulfonic acid) or kaionoids. Besides involvement in biological and physiological processes such as osmoregulation, neuro- and immunomodulation, and antioxidative protection, taurine shows anti-hypertensive, hypo-cholesterolemic, and hepato-protective effects (Larsen et al. 2014). Kainoids are a group with structures and functions similar to those of aspartic and glutamic acids (Smit 2004). Among kainoids, kainic and domoic acids have attracted considerable interest due to their high insecticidal, anthelmintic, and neuroexcitatory properties (Parsons 1996). Moreover, extracts of the red seaweeds Digenea simplex and Chondria armata containing kainic and domoic acid, respectively, have been used for centuries in Japan as anthelmintic agents in the treatment of ascariasis (Smit 2004).

(e) Lipids: Lipids in seaweeds represent up to $\sim 5 \%$ on a dry weight basis and, although this content is lower than that found in other marine organisms and oil seeds, the lipid fraction contains several important major bioactive components such as omega-3 and omega-6 polyunsaturated fatty acids (n-3 PUFAs), oxylipins and glycolipids. PUFAs are classified into two families based on their metabolic pathway.
Several species of Rhodophyta can be an important source of very long chains of n-3 and n-6 PUFAs, which represent $10-70 \%$ of total fatty acids (Mišurcová et al. 2011). Seaweeds are a marine source of important $n-3$ PUFAs, such as docosahexaenoic acid (DHA) and eicosapentaenoic acid (EPA) and alpha-linolenic acid (ALA). Red and brown algae contain relatively high concentrations of EPA while green algae are rich in ALA. The positive health effects of marine PUFAs, in particular the n-3 PUFAs, are well known for the prevention of many chronic diseases and cancers (D’Archivio et al. 2018). Hence, marine n-3 PUFAs are common ingredients in functional food formulations (Kumari et al. 2013). Various types of oxygenated fatty acids are involved in responses to physical damage by pathogens. It seems that oxylipins are involved with the innate immunity of marine algae in response to biotic and abiotic stresses (Bouarab et al. 2004). Red seaweeds are the most prolific source of oxylipins containing a number of complex and unique structures. The occurrence of oxylipins with pharmacological interest has been well documented in Rhodophyta (Barbosa et al. 2016). In comparison with PUFAs, the study of glycolipids synthesized by seaweeds and residing in chloroplast membranes has been mostly neglected. Nevertheless, the interest regarding these compounds has been growing rapidly in recent decades due to their pharmacological potential. Major glycolipids, such as monogalactosyldiacylglycerol (MGDG), digalactosyldiacylglycerol (DGDG) and sulfoquinovosyldiacylglycerol (SQDG), have been reported to exhibit diverse bioactive properties such as anti-bacterial, anti-tumor, anti-viral and anti-protozoal (Ohta et al. 1998, Wang et al. 2007, Cantillo-Ciau et al. 2010, de Souza et al. 2012, Sangha et al. 2013, Plouguerné et al. 2014).

\section{Metabolites from seaweeds active against NTDs}

\section{Seaweed metabolites against trypanosomiasis}

Trypanosomiasis is a vector-borne NTD caused by the kinetoplastid parasite genus Trypanosoma and transmitted to humans by tsetse fly (Glossina genus) or triatomine bug bites (Table 1). The human African trypanosomiasis (HAT), also known as sleeping sickness, is caused by Trypanosoma brucei gambiense and Trypanosoma brucei 
rhodesiense and is common in Africa, while Trypanosoma cruzi is responsible for Chagas' disease, which is common in Latin America. More than 10,000 people die annually due to Chagas' disease with 25 million people at risk of acquiring the disease. Thanks to the efforts of WHO, national control programmes, bilateral cooperation and NGOs, the number of new human African trypanosomiasis cases reported between 2000 and 2012 decreased. Only 2804 new HAT cases have been reported in 2015 (WHO 2018).

The promastigotes and epimastigotes (forms of the parasite in insect hosts), as well as the bloodstream trypomastigotes (human infective forms) have been used in phenotypic screenings, while the latter is the clinically relevant form of the parasite. In Trypanosoma cruzi infection, both the (intracellular) amastigote and the trypomastigote life cycle stages take place in the human host (Jones et al. 2013). As discussed below, the only metabolite class reported from seaweeds with antitrypanosomal activity are terpenes, belonging to sesqui- (C15) and diterpenes (C20) subclasses which are shown in Figure 1: (a) Sesquiterpenes: Several curcuphenol type monocyclic aromatic sesquiterpenes have been obtained from organic extracts of the green alga Udotea orientalis growing on the Papua New Guinean gorgonian coral Pseutopterogorgia rigida (Sabry et al. 2017). The known compound (+)-curcudiol (Figure 1-1) showed the best antitrypanosomal activity against Trypanosoma cruzi amastigotes (the intracellular form of the parasite) with an $\mathrm{IC}_{50}$ value of $10 \mu \mathrm{M}$, although the authors did not report the in vitro efficacy of other isolated compounds. Notably, curcuphenol type sesquiterpenes have been mostly reported from sponges and corals including the soft coral P. rigida.

Several studies have investigated the inhibitory activity and mechanisms of the chlorinated bicyclic sesquiterpene elatol (Figure 1-2), the major component of the Brazilian red seaweed Laurencia dendroidea. Elatol is a small molecule with multiple chiral centers. In the initial work by Veiga-Santos et al. (2010), however, its specific rotation was not measured or mentioned, instead the authors have<smiles>Cc1ccc([C@@H](C)CCCC(C)(C)O)c(O)c1</smiles><smiles>C=C1C[C@H](O)C(Br)C(C)(C)[C@H]1/C=C\CC1(C)CC1C(Cl)Br</smiles>

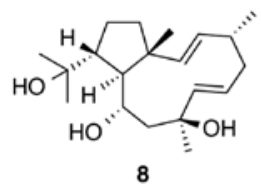<smiles>Cc1cc(C)c2c(c1)C(=O)CC(C)(CC1=C(CC(C)(O)O)C(=O)C3(C)CCCC3(C)C1)O2</smiles>
$11 \mathrm{a} C 3=R$
$11 \mathrm{~b} C 3=\mathrm{S}$<smiles>CC(C)=CCC/C(C)=C/CC/C(C)=C/CC/C(C)=C/CC1(CC(=O)O)CC(=O)C=CC1=O</smiles><smiles>CC(C)=CC(=O)C/C(C)=C/CC/C(C)=C/CC/C(C)=C/CO</smiles><smiles>C=C1CC[C@H](C(C)CCC=C(C)C)C(O)[C@]2(C)C(C)=CC[C@H]12</smiles><smiles>CC(C)=CCCC(C)[C@H]1CC=C(C)[C@@H]2CC=C(C)C1[C@H]2O</smiles>

Figure 1: Seaweed terpenes with trypanocidal and leishmanicidal activity: 1. curcudiol; 2. elatol; 3. eleganolone; 4. bifurcatriol; 5. obtusol; 6. triquinane derivative; 7a. pachydictyol; 7b. isopachydictyol; 8. dolabelladienetriol; 9. 4-acetoxydolastane; 10a. 3R-tetraprenyltoluquinol; 10b. 3S-tetraprenyltoluquinol; 11a. 3R-tetraprenyltoluquinone; 11b. 3S-tetraprenyltoluquinone; 12. Atomaric acid; 13. Atomaric methyl ester derivative acid. 14. Quinone. 15. Fucosterol. 
used only the name elatol, while in follow up studies the name (-)-elatol was used. Herein we use the same trivial names and structures as reported by the authors. This compound inhibited the epimastigote, trypanomastigote and intracellular amastigote forms of Trypanosoma cruzi with $\mathrm{IC}_{50}$ values of 45.4, 1.38 and $1.01 \mu \mathrm{M}$, respectively. For comparison, the reference drugs used in testing different life forms of the parasite exert $\mathrm{IC}_{50}$ values of $7.8 \mu \mathrm{M}$ (benznidazole), $12.8 \mu \mathrm{M}$ (crystal violet) and $24.3 \mu \mathrm{M}$ (benznidazole). Hence elatol is more potent in vitro than the anti-Chagas drug benznidazole against the trypanomastigote and intracellular amastigote forms, that are present in the human host of T. cruzi. Furthermore, elatol shows little toxicity against the mammalian LLCMK $_{2}$ cells (selectivity index 20), and cause three times lower hemolysis (21\%) than amphotericin B at the highest test concentrations (Veiga-Santos et al. 2010). In two follow-up studies, Desoti et al. (2012, 2014) performed mechanistic studies on the trypanocidal activity of (-)-elatol on both life stage forms. On trypomastigotes, (-)-elatol induced polarization of the mitochondrial membrane, mitochondrial superoxide anion formation, loss of cell membrane and DNA integrity. Hence its effect on trypanosomes has been associated with oxidative stress triggered by mitochondrial dysfunction (Desoti et al. 2012). When tested on amastigotes, (-)-elatol again induced the formation of superoxide anions $\left(\mathrm{O}_{2}^{-}\right)$, caused DNA fragmentation and the formation of autophagic compartments. It has been hence concluded that the trypanocidal action of (-)elatol involves the induction of the autophagic and apoptotic death pathways triggered by an imbalance of the redox metabolism of T. cruzi (Desoti et al. 2014).

(b) Diterpenes: Organic extracts of the brown alga Bifurcaria bifurcata collected from different habitats have shown strong antitrypanosomal activity against the bloodstage trypomastigotes of Trypanosoma brucei rhodesiense (Spavieri et al. 2010, Gallé et al. 2013). Bioactivity-guided fractionation of the ethyl acetate (EtOAc) extract of French $B$. bifurcata $\left(\mathrm{IC}_{50}\right.$ $1.7 \mu \mathrm{M}=0.53 \mu \mathrm{g} \mathrm{ml}^{-1}$ ) has yielded the acyclic diterpene eleganolone (Figure 1-3). Eleganolone is the major diterpenoid constituent of the alga and shows moderate growth inhibitory activity against $T$. brucei rhodesiense $\left(\mathrm{IC}_{50} 45 \mu \mathrm{M}=13.7 \mu \mathrm{g} \mathrm{ml}^{-1}\right.$ ) and Trypanosoma cruzi $\left(\mathrm{IC}_{50} 58 \mu \mathrm{M}=17.7 \mu \mathrm{g} \mathrm{ml}^{-1}\right.$ ), with low selectivity indices around or lower than 4. The highest antiprotozoal activity (IC ${ }_{50}$ value $7.9 \mu \mathrm{M}$ ) and selectivity (SI 21.6) observed for eleganolone is towards the blood stage forms of the malaria parasite Plasmodium falciparum
(Gallé et al. 2013). The higher activity observed for the crude extract may be due to a synergistic effect of the other components found in the extract.

Another new, linear diterpene recently isolated from Irish B. bifurcata is bifurcatriol (Smyrniotopoulos et al. 2017). Bifurcatriol (Figure 1-4) is a minor compound and the first acyclic natural product with two stereogenic centers whose absolute stereochemical structure has been elucidated by Vibrational Circular Dichroism (VCD) spectrometry and DP4/NMR analyses. Both African and American trypanosomes were moderately inhibited in vitro by compound 4 with $\mathrm{IC}_{50}$ values of $11.8 \mu \mathrm{g} \mathrm{ml}^{-1}$ (Trypanosoma brucei rhodesiense) and $47.8 \mu \mathrm{g} \mathrm{ml}^{-1}$ (T. cruzi). The cytotoxicity of the compound against mammalian L6 cells is $56.6 \mu \mathrm{g} \mathrm{ml}^{-1}$. Similar to eleganolone, $P$. falciparum is the most susceptible protozoan parasite against bifurcatriol $\left(\mathrm{IC}_{50}\right.$ value $0.65 \mu \mathrm{g} \mathrm{ml}^{-1}$ ).

\section{Seaweed metabolites against leishmaniasis}

Leishmaniasis is another NTD caused by the protozoan parasite genus of Leishmania, which is transmitted by the bite of over 90 species of infected female phlebotomin sandflies (Table 1). The three main forms of the disease threaten large populations in Latin America, Africa, Asia, Middle East and even Mediterranean countries. Visceral leishmaniasis (VL), also known as kala-azar caused by Leishmania donovani and Leishmania infantum is almost always fatal if left untreated. The causative agents of the most widespread form of the disease, cutaneous leishmaniasis (CL) include Leishmania braziliensis and Leishmania amazonensis. The etiological agent of the mucosal leishmaniasis (ML) can be several Leishmania sp. e.g. L. braziliensis and L. amazonensis. Approximately 700,000 to 1 million new cases of leishmaniasis and up to 30,000 deaths occur annually (WHO 2018). The insect (promastigote) and human (amastigote) life stage forms have been used for assessment of the determination of natural products with leishmanicidal activity.

(a) Sesquiterpenes: dos Santos et al. (2011) have tested the leishmanicidal effect of the halogenated sesquiterpene elatol (no specific rotation mentioned), the major component of the Brazilian red seaweed Laurencia dendroida against Leishmania amazonensis. Against the promastigote forms, elatol showed IC $\mathrm{I}_{50}$ and $\mathrm{IC}_{90}$ values of 4.0 and $7.5 \mu \mathrm{M}$, respectively. The activity against the intracellular amastigotes was 10-fold higher $\left(\mathrm{IC}_{50} 0.45 \mu \mathrm{M}\right)$, but the cytotoxicity towards macrophages was less selective $\left(\mathrm{CC}_{50} 1.4 \mu \mathrm{M}\right)$ affording 
a selectivity index (SI) value of 3. Electron microscopy studies showed that elatol caused ultrastructural changes on both promastigote and amastigote forms of the parasite L. amazonensis. This includes remarkable swelling of mitochondrion, destabilization of the plasma membrane and extension of the endoplasmic reticulum, indicating autophagy.

Another Brazilian group (da Silva Machado et al. 2011) has obtained 5 sesquiterpenes by antileishmanial activity-guided isolation of two populations of Laurencia dendroida from the southeastern Brazilian coast. (-)-Elatol showed activity against both promastigote and amastigote forms of Leishmania amazonensis with $\mathrm{IC}_{50}$ values of 9.7 and $4.5 \mu \mathrm{g} \mathrm{ml}^{-1}$, respectively. The toxicity against macrophages was low $\left(\mathrm{IC}_{50} 112.9\right.$ $\mu \mathrm{g} \mathrm{ml}^{-1}$ ). Obtusol (Figure 1-5), a similar sesquiterpene with an additional bromine atom had similar activity towards promastigotes $\left(\mathrm{IC}_{50} 6.2 \mu \mathrm{g} \mathrm{ml}^{-1}\right.$ ), amastigotes $\left(\mathrm{IC}_{50} 3.9 \mu \mathrm{g} \mathrm{ml}^{-1}\right.$ ) and macrophages ( $\mathrm{IC}_{50} 133.5 \mu \mathrm{g} \mathrm{ml}^{-1}$ ). The triquinane derivative (Figure 1-6) had practically identical antileishmanial activity against both life stages ( $\mathrm{IC}_{50}$ values 43.8 and $48.7 \mu \mathrm{g} \mathrm{ml}^{-1}$, respectively) and low toxicity $\left(160.2 \mu \mathrm{g} \mathrm{ml}^{-1}\right)$. None of the compounds promoted the elevated nitric oxide production by macrophages (da Silva Machado et al. 2011).

(b) Diterpenes: Bifurcatriol, a highly oxygenated acyclic diterpene from the brown alga Bifurcaria bifurcata inhibited the growth of amastigotes of Leishmania donovani with an $\mathrm{IC}_{50}$ value of $18.8 \mu \mathrm{g} \mathrm{ml}^{-1}$. As mentioned above its cytotoxicity against mammalian L6 cells is $56.6 \mu \mathrm{g} \mathrm{ml}^{-1}$ (Smyrniotopoulos et al. 2017).

A 3:1 mixture of hydroazulene (prenyl guaiane)type bicyclic diterpenes, pachydictyol and isopachydictyol (Figure 1-7a/7b) has been isolated from the dichloromethane extract of the Brazilian brown alga Dictyota menstrualis that showed significant activity against Leishmania amazonensis promastigotes $\left(\mathrm{IC}_{50}\right.$ $\left.0.75 \mu \mathrm{g} \mathrm{ml}^{-1}\right)$. However the antileishmanial activity of the isolated isomeric mixture is moderate $\left(\mathrm{IC}_{50} 23.5 \mu \mathrm{g}\right.$ $\mathrm{ml}^{-1}$ ) and equal to their toxicity against macrophages $\left(\mathrm{CC}_{50} 30 \mu \mathrm{g} \mathrm{ml}^{-1}\right)$, indicating that the mixture non-selectively inhibits the growth of the parasite (Lira et al. 2016). In Brazil, the co-infection of HIV and mucosal, muco-cutaneous and cutaneous forms of leishmaniasis is very common. Soares et al. (2012) assessed the inhibitory activity of dolabelladienetriol (Figure 1-8, no optical sign stated), a dolabellene-type diterpene, against several life stages of L. amazonensis. The motivation for this study was that dolabelladienetriol is a potent inhibitor of HIV-1 reverse transcriptase enzyme (Cirne-Santos et al. 2008). Based on the activity against promastigotes (95.5\% inhibition at $100 \mu \mathrm{M}$ concentration), the efficacy of dolabelladienetriol was evaluated on intracellular amastigotes. The compound showed only moderate activity ( $\left.\mathrm{IC}_{50} 43.9 \mu \mathrm{M}\right)$. Dolabelladienetriol reduced the NO, transforming growth factors (TNF- $\alpha$ and TGF- $\beta$ ) production and nuclear factor NF- $\mathrm{KB}$ nuclear translocation. Importantly, it inhibited the growth of Leishmania parasites in HIV-1-co-infected human macrophages, making it a promising compound against this disease.

The 4-acetoxydolastane diterpene $(4 R, 9 S, 14 S)$ $4 \alpha$-acetoxy-9 $\beta, 14 \alpha$-dihydroxydolast-1(15),7-diene (Figure 1-9, no optical sign stated) has been isolated by activity-guided extraction of another brown alga, Canistrocarpus cervicornis from Brazil. This tricyclic diterpene (dos Santos et al. 2011) exhibited promising antileishmanial effects with IC $_{50}$ values of $2.0 \mu \mathrm{g}$ $\mathrm{ml}^{-1}, 12.0 \mu \mathrm{g} \mathrm{ml}^{-1}$, and $4.0 \mu \mathrm{g} \mathrm{ml}^{-1}$ against promastigote, axenic amastigote and intracellular amastigote forms, respectively, of Leishmania amazonensis. The compound had a very high selectivity window with a 93-fold higher toxicity to protozoans than the macrophages. Similar to other terpenes, it also caused ultrastructural changes and depolarization in mitochondria, and an increase of lipid peroxidation. This successful compound warrants further studies to identify its exact mechanisms of action.

(c) Meroterpenes: Meroterpenes are terpenes of mixed biogenesis, and are known for their antiprotozoal activity. By applying antileishmanial activity as a guide, de Sousa and coworkers (2017) have isolated the epimeric mixtures of two meroterpenes (3R)and (3S)-tetraprenyltoluquinol (Figure 1-10a/10b) and (3R)- and (3S)-tetraprenyltoluquinone (Figure 1-11a/11b), from the hexane extract of the brown alga Cystoseira baccata collected from Portuguese waters. The hexane extract decreased the viability of the promastigote forms of Leishmania infantum moderately ( $74 \%$ at $250 \mathrm{mg} \mathrm{ml}^{-1}$ concentration), and demonstrated the efficacy of mixtures of these compounds (IC $_{50}$ $44.9 \mu \mathrm{M}$ for (3R)- and (3S)-tetraprenyltoluquinol, and $94.4 \mu \mathrm{M}$ for (3R)- and (3S)-tetraprenyltoluquinone). Their cytotoxicities against mouse peritoneal macrophages were close or similar to each other $\left(\mathrm{IC}_{50} 126.6\right.$ and $84.5 \mu \mathrm{M})$ and to the reference drug miltefosine $(130.3 \mu \mathrm{M})$; however the selectivity was still very low. These compounds also interfered with mitochondria, inducing cytoplasmic vacuolization, and disrupted the mitochondrial membrane (de Sousa et al. 2017).

Atomaric acid (Figure 1-12) is a meroterpene and a major chemical component of the tropical brown 
alga Stypopodium zonale (Dictyotaceae). The lipophilic extract of this seaweed was selected for its high leishmanicidal activity $\left(\mathrm{IC}_{50} 0.27 \mu \mathrm{g} \mathrm{ml}^{-1}\right.$ ) against the amastigotes of Leishmania amazonensis (Costa Soares et al. 2016). Atomaric acid and its semi-synthetically prepared methyl ester derivative (Figure 1-13) was active against $L$. amazonensis promastigotes (up to $100 \%$ inhibition at $100 \mu \mathrm{m}$ ) and inhibited the amastigote forms with $\mathrm{IC}_{50}$ values of $20 \mu \mathrm{M}\left(9 \mu \mathrm{g} \mathrm{ml}^{-1}\right.$, 12) and $23 \mu \mathrm{m}\left(10 \mu \mathrm{g} \mathrm{ml}^{-1}, 13\right)$. When tested on murine peritoneal macrophages, they showed low toxicity with acceptable SI indices around 8 and 20. Nitric oxide and reactive oxygen species (ROS) are potent leishmanicidal mediators. Both compounds $\mathbf{1 2}$ and 13 were found to modulate macrophage activity by inhibiting NO production and stimulating the production of ROS (Soares et al. 2016). Another meroterpene possessing a quinone function (Figure 1-14) has been the subject of a Japanese patent by Kimura et al. (2011). This compound was isolated from the brown alga Sargassum angii (formerly Sargassum yamadae) and reported to exhibit both in vitro and in vivo antileishmanial effects in a mouse model (Kimura et al. 2011).

(d) Sterols (triterpene): Fucosterol is a common triterpene in some brown algae. In a recent study Becerra et al. (2015) isolated fucosterol (Figure 1-15) by using supercritical fluid (SFE) and pressurized solvent (PSE) extraction techniques from the Argentinian brown seaweed Lessonia vadosa. Fucosterol was active against the extracellular promastigotes and intracellular amastigotes of both Leishmania infantum $\left(\mathrm{IC}_{50}\right.$ values 45 and $10.3 \mu \mathrm{M}$, respectively) and Leishmania amazonensis ( $\mathrm{IC}_{50} 55$ and $7.9 \mu \mathrm{M}$, respectively), and posed no toxicity against the host macrophagic cell line $\left(\mathrm{IC}_{50}>100 \mu \mathrm{M}\right)$. These results may suggest a selective activity towards amastigotes or the immunomodulatory effect of $\mathbf{1 5}$ by modifying the response of macrophages (Becerra et al. 2015).

(e) Sulfated polysaccharides: In in vitro macrophage models, the commercially obtained fucoidan (size not mentioned) eliminated the intracellular amastigotes of both antimony-susceptible and -resistant Leishmania donovani (over 90\% inhibition at $50 \mu \mathrm{M}$ concentration, no IC $_{50}$ determination). Oral administration of fucoidan ( $200 \mathrm{mg} \mathrm{kg}^{-1}$ day $^{-1}, 3$ times weekly) in BALB/c mice infected with in antimony-susceptible and -resistant $L$. donovani achieved full parasite clearance in mouse liver and spleen (Kar et al. 2011). When administered 15 days post-infection, fucoidan evoked resistance to reinfection. This effect has been linked to the direct induction of NO and ROS as well as the switch of CD4 + T cell mediated immune responses. Hence fucoidan appears to have both curative and immunomodulatory activity against $L$. donovani, the causative agent of visceral leishmaniasis (Kar et al. 2011).

Pires et al. (2013) have purified sulfated polysaccharides (with molecular size ranging from $25 \mathrm{kDa}$ to $200 \mathrm{kDa}$ ) from four seaweeds including the red algae, Solieria filiformis, Botryocladia occidentalis and Gracilaria caudata and a green alga Caulerpa racemosa. These polymers were tested in vitro against the promastigotes of Leishmania amazonensis. The most active SP was that obtained from C. racemosa, which displayed an $\mathrm{EC}_{50}$ value of $34.5 \mu \mathrm{g} \mathrm{ml}^{-1}$, while $B$. occidentalis and S. filiformis-derived SPs were less active ( $\mathrm{EC}_{50} 63.7$ and $\left.137.4 \mu \mathrm{g} \mathrm{ml}^{-1}\right)$. However, all three SPs were found to be toxic against J774 macrophages, resulting in selectivity indices ranging from 0.42 to 1.42 .

\section{Seaweed against dengue and other mosquito-borne infections}

Dengue is the most important mosquito-borne viral disease in the world (WHO 2018). Dengue virus (DENV) is an enveloped virus (genus Flavivirus) classified into four different serotypes (DENV-1, -2, -3 and -4), all of them capable of causing the disease. Dengue is transmitted by the bites of female mosquitoes Aedes aegypti and Aedes albopictus that cause a flu-like illness, and occasionally develops into a potentially lethal complication called severe dengue. This mosquito also transmits other closely related enveloped viruses such as Zika (ZIKV) and chikungunya (CHIKV) (Table 1). ZIKV infection is a tremendous risk for pregnant women because ZIKV can seriously damage the brain development of the fetus in utero (WHO 2018). CHIKV virus, an arbovirus of the genus Alphavirus, has significantly expanded its geographical distribution due to increased migration of infected people. Despite the importance of these mosquito-borne viral diseases, treatments are only preventative and/or palliative. Until the recent tetravalent dengue vaccine licensure (Table 1), the only approach to control the transmission of these virus diseases has been through the control of the Aedes mosquito. At present, there are no specific antiviral treatments for these mosquito-borne viral diseases. As is common to the series of enveloped RNA-composed viruses, the viral replicative cycle starts with the attachment of virus to the surface of the host cell; therefore, blocking virus binding is a valuable anti-viral strategy because it allows 
establishment of a first barrier to suppress infection. Because of their ability to change cell surface properties, the antiviral effects of sulfated polysaccharides from seaweeds have been investigated in order to prevent the virus attachment.

(a) Sulfated polysaccharides: Rodrigues et al. (2017) reported a polysulfated fraction called ulvan (containing $11 \%$ sulfate and $6 \%$ uronic acids) from the green alga Caulerpa cupressoides collected in Northeastern Brazil, which showed an effective in vitro activity against DENV-1 in Vero (African green monkey kidney) cell line ( $96 \%$ percentage inhibition, $\mathrm{EC}_{50}$ $\left.0.35 \mu \mathrm{g} \mathrm{ml}^{-1}\right)$ with a high selectivity index $(>714)$ and no cytotoxicity $\left(\mathrm{CC}_{50}>1000 \mu \mathrm{g} \mathrm{ml}^{-1}\right)$. Infrared analysis revealed four SP fractions of distinct molecular weights ranging from 8 to $>100 \mathrm{kDa}$ (Rodrigues et al. 2017). The authors concluded that the strong antiviral activity displayed supported the hypothesis that the sulfation pattern on C- 6 galactose residues was important in the inhibition of infection. They argued that the amount of sulfation (1.8-fold greater than the uronic acid content) and the effect of the chain length (of less than $100 \mathrm{kDa}$ ) could contribute in parallel to the in vitro antiviral effect of ulvan, suggesting that this SP interfered with virion envelope structures or masked viral structures, once they are necessary for adsorption or entry into cells.

In relation to brown seaweeds, the fucoidan of Cladosiphon okamuranus significantly inhibited DENV-2 infection $\left(\mathrm{IC}_{50} 4.7 \mu \mathrm{g} \mathrm{ml}^{-1}\right.$ ) in baby hamster kidney (BHK-21) cells in a dose-dependent manner (Hidari et al. 2008). This fucoidan consists of a repeating unit of sulfated fucose and glucuronic acid residues in a molar ratio of 6.1:1.0:2.9 fucose, glucuronic acid and sulfate, respectively (Nagaoka et al. 1999). Treatment of the virus with $10 \mu \mathrm{g} \mathrm{ml}^{-1}$ fucoidan reduced the infectivity by $20 \%$ compared with that in untreated cells, and two derivatives of this fucoidan generated by chemical modifications, such as elimination of the sulfated group or reduction of carboxylic acid, were also tested (Hidari et al. 2008). A fucose polymer was used for the control experiment. Desulfation from fucoidan showed marked suppression of inhibitory activity to $1 \%$ of that of fucoidan and a carboxy-reduced fucoidan derivative in which glucuronic acid was converted to glucose knocked out the effect of fucoidan against DENV2 infection. DENV2 particles bound exclusively to fucoidan, indicating that both glucuronic acid and sulfated fucose residues were involved in the interaction with envelope glycoprotein on DENV2. Of dengue virus serotypes, the DENV2 strain was highly susceptible to the Cladosiphon fucoidan. DENV3 and DENV4 were moderately susceptible and DENV1 showed no susceptibility. To elucidate the molecular basis of susceptibility to the Cladosiphon fucoidan, the nucleotide sequence of DENV1 was examined and multiple alignment analyses of the amino acid sequences of the proteins of the four serotype strains were performed. Results showed that amino acid residues at positions 295 and 310 (Lys295 and Lys or Arg310) are critically involved in the interaction with sulfated glycosaminoglycans, and contribute to the susceptibility of dengue virus to fucoidan (Hidari et al. 2008).

From Rhodophyta, a novel series of DL-galactan hybrids of the carrageenan- and agaran-types (molecule size ranging from $18 \mathrm{kDa}$ to $77 \mathrm{kDa}$ and sulfate content ranging from 8.6 to $29.2 \%$ ) were isolated from the red seaweed Gymnogongrus torulosus (Estevez et al. 2001). All DL-galactan hybrids showed strong in vitro inhibitory effects against DENV-2 in Vero cells, with $\mathrm{IC}_{50}$ ranging from 0.19 to $1.7 \mu \mathrm{g} \mathrm{ml}^{-1}$ (Pujol et al. 2002). No cytotoxicity was observed with any of the galactans $\left(\mathrm{CC}_{50}>1000 \mu \mathrm{g} \mathrm{ml}^{-1}\right)$ with the exception of only one fraction, which exhibited a $\mathrm{CC}_{50}$ value of $822 \mu \mathrm{g} \mathrm{ml}{ }^{-1}$. Full inhibitory activity was achieved when the galactans were present during the virus adsorption period, confirming that the mode of action of these sulfated compounds is to interfere in the binding of the surface envelope glycoprotein with the cell receptor. The effects of DL-galactans were not reversible, since the withdrawal of the compounds after adsorption did not affect the antiviral activity.

Later, two homogeneous and chemically well characterized SPs obtained from Gymnogongrus griffithsiae and Cryptonemia crenulata, the $\kappa / \mathrm{l} / \mathrm{v}$ carrageenan, and a DL-galactan hybrid (3-linked $\beta$-D-galactose 2- and 2,6-disulfated and 4-linked $\alpha$-D- and $\alpha$-L-galactose 6 - and 2,6-disulfated besides 3,6.anhydro- $\alpha$-D and $\alpha$-L-galactose, with molecular size $236 \mathrm{kDa}$ ) were potent and selective inhibitors in vitro of DENV-2 in Vero cells with $\mathrm{IC}_{50}$ around 1 $\mu \mathrm{g} \mathrm{ml}^{-1}, \mathrm{CC}_{50}>1000 \mu \mathrm{g} \mathrm{ml}^{-1}$, and selectivity indices $>1000$, values comparable to the reference polysaccharides heparin and DS8000 with $\mathrm{IC}_{50} 1.9$ and $0.9 \mu \mathrm{g} \mathrm{ml}^{-1}$, respectively (Talarico et al. 2004, 2005). Nevertheless, these SPs were inactive in mosquito cells, and this differential susceptibility was related to the mode of entry of DENV into diverse cells. The authors concluded that the compounds blocked the initial steps of virus adsorption and internalization into the host cell (Talarico et al. 2007). Afterwards, the authors also assayed commercial iota-, lambda- and kappa-carrageenans for anti-DENV-2 activity in Vero cells and in C6/36 HT cells from Aedes albopictus, as model systems of mammalian and mosquito cells, respectively (Talarico et al. 2011). All commercial polysaccharides 
blocked DENV-2 infection in Vero cells, but only iotacarrageenans were virus inhibitors in mosquito cells. However, iota-carrageenan was less effective in mosquito cells in comparison with mammalian cells with $\mathrm{EC}_{50}$ values in C6/36 HT cells 4.9-17.5-fold higher than in Vero cells, as determined by virus yield reduction assay. The authors reported the mode of action of iota-carrageenan to be strikingly different in both cell types: in Vero cells the inhibitory activity was exerted only at the initiation of the cycle, affecting virion binding. In mosquito cells, iotacarrageenans induced a subtle alteration in cells, detected by cell proliferation and protein synthesis analyses.

In relation to the inhibitory activity of seaweed compounds against ZIKV, very few studies have been completed. A recent study of Cirne-Santos et al. (2017) reported that organic extracts of Kappaphycus alvarezii, Caulerpa racemosa and Osmundaria obtusiloba collected from the Brazilian coast were able to inhibit ZIKV replication above $90 \%$ in Vero cell culture at low concentrations in a dose-dependent manner, with $\mathrm{EC}_{50}$ values of $1.38,1.98$ and $1.82 \mu \mathrm{g} \mathrm{ml}^{-1}$ and selective indices of 306, 369 and 288, respectively. Caulerpa racemosa extract presented the best $\mathrm{CC}_{50}$ with a value of $732 \mu \mathrm{g} \mathrm{ml}^{-1}$, followed by 0 . obtusiloba $\left(525 \mu \mathrm{g} \mathrm{ml}^{-1}\right)$. To identify the step at which viral replication was inhibited, the authors performed a time-course experiment with the compounds administered at $3.2 \mu \mathrm{g} \mathrm{ml}^{-1}$ and $1 \mathrm{~h}$ before infection, time 0 (immediately when virus added) and 1,2 and $3 \mathrm{~h}$ after infection. Ribavirin at $5 \mu \mathrm{m}$ was used as a control. Results showed that at time 0 , all extracts were able to inhibit over $80 \%$ of viral replication and $O$. obtusiloba and Ribavirin maintained the inhibitory effect at the other times. The authors pointed out the significant viricidal effect of $O$. obtusiloba, inhibiting viral replication more than $80 \%$ at a concentration of $10 \mu \mathrm{M}$, showing it to be an excellent preventative agent, especially considering the effect directly on the virus particle. In a previous study, the same group reported the sulfolipid SQDG (1,2-di-O-acyl-3-O-(6-deoxy-6-sulfo- $\alpha$-D-glucopyranosyl)$s n$-glycerol) for this species, which also showed a potent antiviral activity against HSV-1 $\left(\mathrm{EC}_{50} 42 \mu \mathrm{g} \mathrm{ml}^{-1}\right)$ and HSV-2 $\left(\mathrm{EC}_{50} 12 \mu \mathrm{g} \mathrm{ml}^{-1}\right.$ ) (de Souza et al. 2012).

In relation to the mosquitocidal seaweed compounds, $\mathrm{Yu}$ et al. (2014) pointed out in a recent review that the halogenated sesquiterpene (-)-elatol from Laurencia dendroidea showed potent larvicidal effects ( $>91 \%$ mortality at $50 \mathrm{ppm}$, with lethal concentration $50\left(\mathrm{LC}_{50}\right)$ of $\left.10.7 \mathrm{ppm}\right)$ against Aedes aegypti larvae, while several fatty acids (capric, lauric, and myristic and palmitoleic acids) isolated from Cladophora glomerata showed activity against Aedes triseriatus, showing $\mathrm{LC}_{50}$ values ranging from 3 to $14 \mathrm{ppm}$. More recently, Salvador-Neto et al. (2016) corroborated the larvicidal effect against $A$. aegypti of elatol and another halogenated sesquiterpene, (+)-obtusol, isolated from $L$. dendroidea. Elatol showed larvicidal activity with 10 ppm killing approximately $30 \%$ of the larvae within $24 \mathrm{~h}$ and at lower concentrations than elatol. However, using a concentration of $10 \mathrm{ppm},(+)$-obtusol killed approximately $90 \%$ of $A$. aegypti larvae and, at lower concentrations, $(+)$-obtusol showed a reasonable larvicidal activity. It was noted that (+)-obtusol acted in a dose-dependent manner with $\mathrm{LC}_{50}$ of $3.5 \mathrm{ppm}$. Moreover, histological analysis of the larvae exposed to (+)-obtusol revealed damage to the intestinal epithelium. Structurally, elatol and (+)-obtusol differ in only one double bond and the presence of an additional bromine atom (Salvador-Neto et al. 2016). The authors suggested that the presence of this additional bromine could be responsible for the increase in potency when compared to elatol.

\section{Seaweed metabolites against schistosomiasis}

Human schistosomiasis (also known as bilharzia, bilharziosis or snail fever) is a chronic parasitic disease caused by trematode flukes of the genus Schistosoma, which globally affects over 250 million people (WHO 2018). Among the Schistosoma species, Schistosoma mansoni is the most widely spread in Africa and Latin America. The adult male and female worms live within the veins of their human host, where they mate and produce fertilized eggs. The eggs are either shed into the environment through feces or urine or are retained in host tissues inducing a distinct immune-mediated granulomatous response that causes local and systemic pathological effects. These effects range from anemia, growth stunting, impaired cognition, and decreased physical fitness, to organ-specific effects such as severe hepatosplenism, periportal fibrosis with portal hypertension, and urogenital inflammation and scarring. In general, compounds with schistosomicidal activity lead to disruption of mating of males and females and alterations in the morphology or constitution of the protective tegument, or changes in the muscle activity of the parasite. There is currently only one method of treatment (monotherapy), the isoquinolinone drug praziquantel to suppress morbidity (Table 1). However, constant selection pressure through mass chemotherapy has yielded evidence of resistance to praziquantel. As discussed below, only one recent preliminary study on seaweeds with antischistosomal activity has been carried (Stein et al. 2015). In this study, the efficacies of 13 organic extracts of seaweeds from Brazil were tested in vitro against $S$. mansoni in a first 
trial, and the active extracts (at $500 \mu \mathrm{g} \mathrm{ml}^{-1}$ exposure) were further evaluated at lower concentrations $\left(100 \mu \mathrm{g} \mathrm{ml} \mathrm{m}^{-1}\right)$. Worm couples were incubated with different concentrations of seaweed extracts for $120 \mathrm{~h}$ and monitored after the first $2 \mathrm{~h}$ and then every $24 \mathrm{~h}$ to evaluate death, mobility reduction and couple detachment. Only extracts of Gracilaria ornata, as well as species belonging to the genera Dictyota (Dictyota dichotoma, Dictyota menstrualis and Dictyota mertensii and Laurencia (Laurencia catarinensis and Laurencia dendroidea) showed high activity at 100 $\mu \mathrm{g} \mathrm{ml}^{-1}$, with couple worm death time ranging from 24 to $120 \mathrm{~h}$. The active extracts were analyzed chromatographically applying a UPLC-MS system in search of a common metabolite among all of the seaweeds. Stein et al. (2015) found an abundance $(95 \%)$ of low weight molecules $(<500$ Da with a retention time of $76.1 \mathrm{~min}$ ), indicating a similar secondary metabolite in the extracts (hexanoic and chloroformic extracts) with the molecular weight of a sesterterpene or a conjugated diterpene. From the three most active extracts, defined by the total mortality reached in $24 \mathrm{~h}$, D. menstrualis and L. catarinensis yielded a common molecular weight of $181.123 \mathrm{Da}$, with a retention time of 36.1 min which coincided with the molecular weight of a sesquiterpene or a conjugated monoterpene.

\section{Conclusion and perspectives}

The NTDs are the most common infections in the world and, in recent decades, a new impulse to drug discovery from marine sources has been observed. In particular, the investigation of different biological activities of extracts and pure compounds isolated from seaweeds collected from different geographical areas has yielded natural products with promising activities against NTDs. However these investigations have covered only the very early stages of the drug discovery process. The discovery of new algal compounds to combat NTDs is useful, and overall improvements in bioassays and the recent development of new tools will help to improve our understanding of the characteristics needed for a compound to progress toward preclinical development. In this review, we have addressed the research conducted on seaweed-derived molecules against the most studied NTDs. Based on their chemical structures, bioactive compounds reported from the identified seaweeds belong to several chemical groups, with the highest proportion belonging to terpenoids and sulfated polysaccharides that warrant further studies in the development of alternative or complementary therapies for NTDs.
Acknowledgments: The authors thank Nutraceuticos de algas marinas, PN-CONACYT 2015-01-118 project for research funding and financial support.

\section{References}

Afolayan, A.F., M.G.A. Mann, C.A. Lategan, P.J. Smith, J.J. Bolton and D.R. Beukes. 2009. Antiplasmodial halogenated monoterpenes from the marine red alga Plocamium cornutum. Phytochemistry 70: 597-600.

Al-Massarani, A.M. 2014. Phytochemical and biological properties of sesquiterpene constituents from the marine red seaweed Laurencia: a review. Nat. Prod. Chem. Res. 2: 147.

Ananthi, S., H.R. Raghavendran, A.G. Sunil, V. Gayathri, G. Ramakrishnan and H.R. Vasanthi. 2010. In vitro antioxidant and in vivo anti-inflammatory potential of crude polysaccharide from Turbinaria ornata (marine brown alga). Food Chem. Toxicol. 48: 187-192.

Barbosa, M., P. Valentão and P.B. Andrade. 2016. Biologically active oxylipins from enzymatic and nonenzymatic routes in macroalgae. Mar. Drugs 14: 23-48.

Becerra, M., S. Boutefnouchet, O. Cordoba, G.P. Vitorino, L. Brehu, I. Lamour, F. Laimay, A. Efstathiou, D. Smirlis, S. Michel, M. Kritsanida, M.L. Flores and R. Grougnet. 2015. Antileishmanial activity of fucosterol recovered from Lessonia vadosa Searles (Lessoniaceae) by SFE, PSE and CPC. Phytochem. Lett. 11: 418-423.

Bio Ventures for Global Health (BVGH). Developing new drugs and vaccines for neglected diseases of the poor: the product developer landscape. https://bvgh.org/neglected-disease-productpipelines/ntd-pipelines/. Accessed 20 February 2018.

Blunt, J.W., R. Brent, B.R. Copp, W-P. Hu, M.G.H. Munro, P.T. Northcote and M.R. Prinsep. 2009. Marine natural products. Nat. Prod. Rep. 26: 170-244.

Blunt, J.W., B.R. Copp, R.A. Keyzers, M.H. Munro and M.R. Prinsep. 2013. Marine natural products. Nat. Prod. Rep. 30: 237-323.

Bouarab, K., F. Adas, E. Gaquerel, B. Kloareg, J.P. Salaün and P. Potin. 2004. The innate immunity of a marine red alga involves oxylipins from both the eicosanoid and octadecanoid pathways. Plant Physiol. 135: 1838-1848.

Bucher, C., R.M. Deans and N.Z. Burns. 2015. Highly selective synthesis of halomon, plocamenone, and isoplocamenone. J. Am. Chem. Soc. 137: 12784-12787.

Cabrita, M.T., C. Vale and A.P. Rauter. 2010. Halogenated compounds from marine algae. Mar. Drugs 8: 2301-2307.

Cantillo-Ciau, Z., R. Moo-Puc, L. Quijano and Y. Freile-Pelegrín. 2010. The tropical brown alga Lobophora variegata: a source of antiprotozoal compounds. Mar. Drugs 8: 1292-1304.

Carlucci, M.J., M. Ciancia, M.C. Matulewicz, A.S. Cerezo and E.B. Damonte. 1999. Antiherpetic activity and mode of action of natural carrageenans of diverse structural types. Antivir. Res. 43: 93-102.

Chale-Dzul, J., R. Moo-Puc, D. Robledo and Y. Freile-Pelegrín. 2015. Hepatoprotective effect of the fucoidan from the brown seaweed Turbinaria tricostata. J. Appl. Phycol. 27: 2123-2135.

Chen, Y., T. Maguire, R.E. Hileman, J.R. Fromm, J.D. Esko, R.J. Linhardt and R.M. Marks. 1997. Dengue virus infectivity depends on envelope protein binding to target cell heparan sulfate. Nat. Med. 3: 866-871. 
Chen, J., H. Li, Z. Zhao, X. Xia, B. Li, J. Zhang and X. Yan. 2018. Diterpenes from the marine algae of the genus Dictyota. Mar. Drugs 16: 1-159.

Cirne-Santos, C.C., T.M. Souza, V.L. Teixeira, C.F. Fontes, M.A. Rebello, L.R. Castello-Branco, C.M. Abreu, A. Tanuri, I.C. Frugulhetti and D.C. Bou-Habib. 2008. The dolabellane diterpene dolabelladienetriol is a typical noncompetitive inhibitor of HIV-1 reverse transcriptase enzyme. Antiviral Res. 77: 64-71.

Cirne-Santos, C.C., C.D.S. Barros, C. Richter Nogueira, R. Mendonça Campos, V. Teixeira, D. Ferreira and I.C.N.D.P. Paixão. 2017. Inhibition of Zika virus by marine algae. Preprints 2017030087 (doi: 10.20944/preprints201703.0087.v1).

Cohen, J.P., L. Silva, A. Cohen, J. Awatin and R. Sturgeon. 2016. Progress report on neglected tropical disease drug donation programs. Clin. Ther. 38: 1193-1204.

Costa Soares, D., M. Macedo Szlachta, V. Laneuville Teixeira, A. Ribeiro Soares and E.M. Saraiva. 2016. The brown alga Stypopodium zonale (Dictyotaceae): a potential source of anti-Leishmania drugs. Mar. Drugs 14: 163.

Cunha, L. and A. Grenha. 2016. Sulfated seaweed polysaccharides as multifunctional materials in drug delivery applications. Mar. Drugs 14: 1-42.

da Silva Machado, F.L., W. Pacienza-Lima, B. Rossi-Bergmann, L.M. Gestinari, M.T. Fujii, J. Campos de Paula, S.S. Costa, N.P. Lopes, C.R. Kaiser and A.R. Soares. 2011. Antileishmanial sesquiterpenes from the Brazilian red alga Laurencia dendroidea. Planta Med. 77: 733-735.

Dai-Hung, N. and K. Se-Kwon. 2013. Sulfated polysaccharides as bioactive agents from marine algae. Int. J. Biol. Macromol. 62: 70-75.

D’Archivio, M., B. Scazzocchio, R. Varì, C. Santangelo, C. Giovannini and R. Masella. 2018. Recent evidence on the role of dietary PUFAs in cancer development and prevention. Curr. Med. Chem. 25: 1818-1836.

de Sousa, C.B., K.N. Gangadhar, T.R. Morais, G.A. Conserva, C. Vizetto-Duarte, H. Pereira, M.D. Laurenti, L. Campino, D. Levy, M. Uemi, L. Barreira, L. Custódio, L.F. Passero, J.H. Lago and J. Varela. 2017. Antileishmanial activity of meroditerpenoids from the macroalgae Cystoseira baccata. Exp. Parasitol. 174: 1-9.

de Souza, L.M., G.L. Sassaki, M.T.V. Romanos and E. BarretoBergter. 2012. Structural characterization and anti-HSV-1 and HSV-2 activity of glycolipids from the marine algae Osmundaria obtusiloba isolated from Southeastern Brazilian coast. Mar. Drugs 10: 918-931.

Desoti, V.C., D. Lazarin-Bidóia, D.B. Sudatti, R.C. Pereira, A. Alonso, T. Ueda-Nakamura, B.P. Dias Filho, C.V. Nakamura and S. de Oliveira Silva. 2012. Trypanocidal action of (-)-elatol involves an oxidative stress triggered by mitochondria dysfunction. Mar. Drugs 10: 1631-1646.

Desoti, V.C., D. Lazarin-Bidóia, D.B. Sudatti, R.C. Pereira, T. UedaNakamura, C.V. Nakamura and S. de Oliveira Silva. 2014. Additional evidence of the trypanocidal action of (-)-elatol on amastigote forms through the involvement of reactive oxygen species. Mar. Drugs. 12: 4973-4983.

di Procolo, P. and C. Jommi. 2014. Current pipelines for neglected diseases. PLoS Negl. Trop. Dis. 8: e3092.

dos Santos, A.O., E.A. Britta, E.M. Bianco, T. Ueda-Nakamura, B.P. Filho, R.C. Pereira and C.V. Nakamura. 2011. 4-Acetoxydolastane diterpene from the Brazilian brown alga Canistrocarpus cervicornis as antileishmanial agent. Mar. Drugs 9: 2369-2383.
Estevez, J.M., M. Ciancia and A.S. Cerezo. 2001. DL-galactan hybrids and agarans from gametophytes of the red seaweed Gymnogongrus torulosus. Carbohydr. Res. 331: 27-41.

Falkenberg, M., E. Nakano, L. Zambotti-Villela, G.A. Zatelli, A.C. Philippus, K. Braga Imamura, A.M. Arenas Velasquez, R.P. Freitas, L. de Freitas Tallarico, P. Colepicolo and M.A.S. Graminha. 2018. Bioactive compounds against neglected diseases isolated from macroalgae: a review. J. Appl. Phycol. https://doi. org/10.1007/s10811-018-1572-5 (accessed: 11 September 2018).

Fleurence, J. 2004. Seaweed proteins. In: (R.Y. Yada, ed) Proteins in food processing. Woodhead Publishing, Cambridge. pp. 197-213.

Fuller, R.W., J.H. Cardellina II, Y. Kat, L.S. Brinen, J. Clardy, K.M. Snader and M.R. Boyd. 1992. A pentahalogenated monoterpene from the red alga Portieria hornemannii produces a novel cytotoxicity profile against a diverse panel of human tumor cell lines. J. Med. Chem. 35: 3007-3011.

Gallé, J.B., B. Attioua, M. Kaiser, A.M. Rusig, A. Lobstein and C. Vonthron-Senecheau. 2013. Eleganolone, a diterpene from the French marine alga Bifurcaria bifurcata inhibits growth of the human pathogens Trypanosoma brucei and Plasmodium falciparum. Mar. Drugs 11: 599-610.

Glazer, A.N. 1994. Phycobiliproteins - a family of valuable, widely used fluorophores. J. Appl. Phycol. 6: 105-112.

Hamann, M.T., C.S. Otto, P.J. Scheuer and D.C. Dunbar. 1996. Kahalides: bioactive peptides from a marine mollusk Elysia rufescens and its algal diet Bryopsis sp. J. Org. Chem. 61: 6594-6600.

Harnedy, P.A. and R.J. FitzGerald. 2011. Bioactive proteins, peptides, and amino acids from macroalgae. J. Phycol. 47: 218-232.

Hartmann, A., K. Becker, U. Karsten, D. Remias and M. Ganzera. 2015. Analysis of mycosporine-like amino acids in selected algae and cyanobacteria by hydrophilic interaction liquid chromatography and a novel MAA from the red alga Catenella repens. Mar. Drugs 13: 6291-6305.

Hayashi, K., T. Nakano, M. Hashimoto, K. Kanekiyo and T. Hayashi. 2008. Defensive effect of a fucoidan from brown alga Undaria pinnatifida against herpes simplex virus infection. Int. Immunopharmacol. 8: 109-116.

Hidari, K.I.P.J., N. Takahashi, M. Arihara, M. Nagaoka, K. Morita and T. Suzuki. 2008. Structure and anti-dengue virus activity of sulfated polysaccharide from a marine alga. Biochem. Biophys. Res. Commun. 376: 91-95.

Hotez, P.J. 2010. A plan to defeat neglected tropical diseases. Sci. Am. 302: 90-94.

Hotez, P.J. 2013. NTDs V.2.0: "Blue Marble Health" - neglected tropical disease control and elimination in a shifting health policy landscape. PLoS Negl. Trop. Dis. 7: e2570.

Hotez, P.J. 2017. Ten failings in global neglected tropical diseases control. PLoS Negl. Trop. Dis. 11: e0005896.

Hotez, P.J., D.H. Molyneux, A. Fenwick, J. Kumaresan, S.E. Sachs, J.D. Sachs and L. Savioli. 2007. Control of neglected tropical diseases. New Eng. J. Med. 357: 1018-1027.

Hotez, P.J., B. Pecoul, S. Rijal, C. Boehme, S. Aksoy, M. Malecela, R. Tapia-Conyer and J.C. Reeder. 2016. Review. Eliminating the neglected tropical diseases: translational science and new technologies. PLoS Negl. Trop. Dis. 10: e0003895.

Huskens, D. and D. Schols. 2012. Algal lectins as potential HIV microbicide candidates? Mar. Drugs 10: 1476-1497. 
Jiao, G., G. Yu, J. Zhang and H.S. Ewart. 2011. Chemical structures and bioactivities of sulfated polysaccharides from marine algae. Mar. Drugs 9: 196-223.

Jones, A.J., T. Grkovic, M.L. Sykes and V.M. Avery. 2013. Trypanocidal activity of marine natural products. Mar. Drugs 11: 4058-4082.

Kang, H.K., C.H. Seo and Y. Park. 2015. Review marine peptides and their anti-infective activities. Mar. Drugs 13: 618-654.

Kar, S., G. Sharma and K.D. Pijush. 2011. Fucoidan cures infection with both antimony-susceptible and -resistant strains of Leishmania donovani through Th1 response and macrophagederived oxidants. J. Antimicrob. Chemother. 66: 618-625.

Karsten, U., T. Sawall, D. Hanelt, K. Bischof, F.L. Figueroa, A. FloresMoya and C. Wiencke. 1998. An inventory of UV absorbing mycosporine-like amino acids in macroalgae from polar to warm-temperate regions. Bot. Mar. 41: 443-453.

Kim, S.K. and I. Wijesekara. 2010. Development and biological activities of marine-derived bioactive peptides: A review. J. Funct. Foods 2: 1-9.

Kimura, J., J. Horie, H. Marushima, Y. Matsumoto, C. Sanjoba and Y. Osada. 2011. Anti-leishmanial agent containing Sargassum brown alga-derived terpene compound. Jpn. Tokkyo Koho, Japanese Patent: JP 4762381 B1 20110831.

Kumari, P., M. Kumar, C.R.K. Reddy and B. Jha. 2013. Algal lipids, fatty acids and sterols. In: (H. Dominguez, ed.) Functional ingredients from algae for foods and nutraceuticals. Woodhead Publishing Ltd, Sawston, Cambridge, UK. pp. 87-134.

Lane, A.L., E.P. Stout, A.S. Lin, J. Prudhomme, K. Le Roch, C.R. Fairchild, S.G. Franzblau, M.E. Hay, W. Aalbersberg and J. Kubanek. 2009. Antimalarial bromophycolides J-Q from the Fijian red alga Callophycus serratus. J. Org. Chem. 74: 2736-2742.

Larsen, R., K-E. Eilertsen, H. Mæhre, I-J. Jensen and E.O. Elvevoll. 2014. Taurine content in marine foods: beneficial health effects. In: (B. Hernández-Ledesma and M. Herrero, eds.) Bioactive compounds from marine foods: plant and animal sources. John Wiley \& Sons, Ltd, Hoboken, NJ, USA. pp. 249-268.

Lira, M.L.F., L. Lopes, A.P. Gomes, G. Barcellos, M. Verícimo, K. Osako, F.A. Ortiz-Ramirez, C.J.B. Ramos, D.N. Cavalcanti, V.L. Teixeira and V. do Amaral. 2016. Anti-leishmanial activity of Brazilian green, brown, and red algae. J. Appl. Phycol. 28: 591-598.

Lowenthal, R.M. and J.H. Fitton. 2015. Are seaweed-derived fucoidans possible future anti-cancer agents? J. Appl. Phycol. 27: 2075-2077.

Máximo, P., L.M. Ferreira, P. Branco, P. Lima and A. Lourenço. 2018. Secondary metabolites and biological activity of invasive macroalgae of Southern Europe. Mar. Drugs 16: 265.

Mišurcová, L., J. Ambrožová and D. Samek. 2011. Seaweed lipids as nutraceuticals. Adv. Food Nutr. Res. 64: 339-355.

Nagaoka, M., H. Shibata, I. Kimura-Takagi, S. Hashimoto, K. Kimura, T. Makino, R. Aiyama, S. Ueyama and T. Yokokura. 1999. Structural study of fucoidan from Cladosiphon okamuranus TOKIDA, Glycoconj. J. 16: 19-26.

Ohta, K., Y. Mizushina, N. Hirata, M. Takemura, F. Sugawara, A. Matsukage, S. Yoshida and K. Sakaguchi. 1998. Sulfoquinovosyldiacylglycerol, KM043, a new potent inhibitor of eukaryotic DNA polymerases and HIV-reverse transcriptase type 1 from a marine red alga, Gigartina tenella. Chem. Pharm. Bull. 46: 684-686.

Parsons, A.F. 1996. Recent developments in kainoid amino acid chemistry. Tetrahedron 52: 4149-4174.
Pedrique, B., N. Strub-Wourgaft, C. Some, P. Olliaro, P. Trouiller, N. Ford, B. Pécoul and J.H. Bradol. 2013. The drug and vaccine landscape for neglected diseases (2000-11): a systematic assessment. Lancet Glob. Health 1: e371-379.

Pereira, R.C. and L.V. Costa-Lotufo. 2012. Bioprospecting for bioactives from seaweeds: potential, obstacles and alternatives. Braz. J. Pharmacog. 22: 894-905.

Pires, C.L., S.D. Rodrigues, D. Bristot, H.H. Gaeta, D. de Oliveira Toyama, W.R. Lobo Farias and M.H. Toyama. 2013. Evaluation of macroalgae sulfated polysaccharides on the Leishmania (L.) amazonensis promastigote. Mar Drugs. 11: 934-943.

Plouguerné, E., B.A.P. da Gama, R.C. Pereira and E. Barreto-Bergter. 2014. Glycolipids from seaweeds and their potential biotechnological applications. Front. Cell. Infect. Microbiol. 4: 1-174.

Pujol, C.A., J.M. Estévez, M.J. Carlucci, M. Ciancia, A.S. Cerezo and E.B. Damonte. 2002. Novel DL-galactan hybrids from the red seaweed Gymnogongrus torulosus are potent inhibitors of herpes simplex virus and dengue virus. Antivir. Chem. Chemother. 13: 83-89.

Ragan, M.A. and K.W. Glombitza. 1986. Phlorotannins, brown algal polyphenols. In: (F.E. Round and D.J. Chapman, eds.) Progress in phycological research. Biopress Ltd, Bristol, UK. pp. 129-241.

Rodrigues, J.A.G., Y.R. Gomes Eloy, E. de Sousa Oliveira Vanderlei, J. Figueiredo Cavalcante, M.T. Villela Romanos and N.M. Barros Benevides. 2017. An anti-dengue and anti-herpetic polysulfated fraction isolated from the coenocytic green seaweed Caulerpa cupressoides inhibits thrombin generation in vitro. Acta Sci. Biol. Sci. 39: 149-159.

Sabry, O.M.M., D.E. Goeger and W.H. Gerwick. 2017. Bioactive new metabolites from the green alga Udotea orientalis growing on the gorgonian coral Pseudopterogorgia rigida. Nat. Prod. Res. 31: 1245-1250.

Salvador-Neto, O., S. Azevedo Gomes, A. Ribeiro Soares, F. Lacerda da Silva Machado, R.I. Samuels, R. Nunes da Fonseca, J. SouzaMenezes, J.L. da Cunha Moraes, E. Campos, F. Borges Mury and J.R. Silva. 2016. Larvicidal potential of the halogenated sesquiterpene (+)-obtusol, isolated from the alga Laurencia dendroidea J. Agardh (Ceramiales: Rhodomelaceae), against the dengue vector mosquito Aedes aegypti (Linnaeus) (Diptera: Culicidae). Mar. Drugs 14: 20.

Samarakoon, K. and Y.J. Jeon. 2012. Bio-functionalities of proteins derived from marine algae. A review. Food Res. Int. 48: 948-960.

Sangha, J.S., D. Fan, A.H. Banskota, R. Stefanova, W. Khan, J. Hafting, J. Craigie, A.T. Critchley and B. Prithiviraj. 2013. Bioactive components of the edible strain of red alga, Chondrus crispus, enhance oxidative stress tolerance in Caenorhabditis elegans. J. Funct. Foods 5: 1180-1190.

Scott, L.G. 2016. Tetravalent dengue vaccine: a review in the prevention of dengue disease. Drugs 76: 1301-1312.

Smit, J.A. 2004. Medicinal and pharmaceutical uses of seaweed natural products: A review. J. Appl. Phycol. 16: 245-262.

Smyrniotopoulos, V., C. Merten, M. Kaiser and D. Tasdemir. 2017. Bifurcatriol, an antiprotozoal acyclic diterpene from the brown alga Bifurcaria bifurcata. Mar. Drugs 15: 245.

Soares, D.C., T.C. Calegari-Silva, U.G. Lopes, V.L. Teixeira, I.C.N. de Palmer Paixao, C. Cirne-Santos, D.C. Bou-Habib and E.M. Saraiva. 2012. Dolabelladienetriol, a compound from Dictyota pfaffii algae, inhibits the infection by Leishmania amazonensis. PLoS Negl. Trop. Dis. 6: e1787. 
Soares, D.C., M.M. Szlachta, V.L. Teixeira, A.R. Soares and E.M. Saraiva. 2016. The brown alga Stypopodium zonale (Dictyotaceae): A potential source of anti-leishmania drugs Mar. Drugs 14: 163.

Souza de Oliveira, L., D.A. Tschoeke, A. Santos de Oliveira, L.J. Hill, W. Costa Paradas, L. Tavares Salgado, C. Carneiro Thompson, R. Crespo Pereira and F.L. Thompson. 2015. New insights on the terpenome of the red seaweed Laurencia dendroidea (Florideophyceae, Rhodophyta). Mar. Drugs 13: 879-902.

Spavieri, J., A. Allmendinger, M. Kaiser, R. Casey, S. Hingley-Wilson, A. Lalvani, M.D. Guiry, G. Blunden and D. Tasdemir. 2010. Antimycobacterial, antiprotozoal and cytotoxic potential of twenty-one brown algae (Phaeophyceae) from British and Irish waters. Phytother. Res. 24: 1724-1729.

Stadnichuk, I.N. and I.V. Tropin. 2017. Phycobiliproteins: structure, functions and biotechnological applications. Appl. Biochem. Microbiol. 53: 1-10.

Stein, E.M., L.P. Machado, H.K. Roffato, P.A. Miyasato, E. Nakano, P. Colepicolo and D.X. Andreguett. 2015. Antischistosomal activity from Brazilian marine algae. Rev. Bras. Farmacog. 25: 663-667.

Talarico, L.B., R.G.M. Zibetti, P.C.S. Faria, L.A. Scolaro, M.E. Duarte, M.D. Noseda, C.A. Pujol and E.B. Damonte. 2004. Anti-herpes simplex virus activity of sulfated galactans from the red seaweeds Gymnogongrus griffithsiae and Cryptonemia crenulata. Int. J. Biol. Macromol. 34: 63-71.

Talarico, L.B., C.A. Pujol, R.G. Zibetti, P.C. Faria, M.D. Noseda, M.E. Duarte and E.B. Damonte. 2005. The antiviral activity of sulfated polysaccharides against dengue virus is dependent on virus serotype and host cell. Antivir. Res. 66: 103-110.

Talarico, L.B., M.E. Duarte, R.G. Zibetti, M.D. Noseda and E.B. Damonte. 2007. An algal-derived DL-galactan hybrid is an efficient preventing agent for in vitro dengue virus infection. Planta Med. 73: 1464-1468.

Talarico, L.B., M.D. Noseda, D.R.B. Ducatti, M.E.R. Duarte and E.B. Damonte. 2011. Differential inhibition of dengue virus infection in mammalian and mosquito cells by iota-carrageenan. J. Gen. Virol. 92: 1332-1342.

Trouiller, P., P. Olliaro, E. Torreele, J. Orbinski, R. Laing and N. Ford. 2002. Drug development for neglected diseases: a deficient market and a public-health policy failure. Lancet 359: 2188-2194.

Utzinger, J., S.L. Becker, S. Knopp, J. Blum, A.L. Neumayr, J. Keiser and C.F. Hatz. 2012. Neglected tropical diseases: diagnosis, clinical, management, treatment and control. Swiss Med. Wkly. 142: w13727.

Vasquez, R., J. Apostol, R.D. Ramos, M. Morales, K. Padiernos, K. Pangilinan, C. Payuran and J. Princesa. 2012. Hepatoprotective effects of aqueous sulfated polysaccharide extract from Sargassum siliquosum JG Agardh on paracetamol-induced oxidative liver toxicity and antioxidant properties. Int. J. Pharm. Front. Res. 2: 15-27.

Veiga-Santos, P., K.J. Pelizzaro-Rocha, A.O. Santos, T. Ueda-Nakamura, B.P. Dias Filho, S.O. Silva, D.B. Sudatti, E.M. Bianco, R.C. Pereira and C.V. Nakamura. 2010. In vitro antitrypanosomal activity of elatol isolated from red seaweed Laurencia dendroidea. Parasitology 137: 1661-1670.

Vonthron-Sénécheau, C. 2016. Medicinal properties: antibiotic, tonic, and, antiparasitic properties. In: (J. Fleurence and I. Levine, eds.) Seaweeds and health and disease prevention. Academic Press, Cambridge, MA, USA. pp. 369-388.

Wang, H., Y.L. Li., W.Z. Shen, W. Rui, X.J. Ma and Y.Z. Cen. 2007. Antiviral activity of a sulfoquinovosyldiacylglycerol (SQDG) compound isolated from the green alga Caulerpa racemosa. Bot. Mar. 50: 185-190.
Weish, O., H.M. Al-Abdely, M.C. Salinas-Carmona and A.H. Fahal. 2014. Review. Mycetoma medical therapy. PLoS Negl. Trop. Dis. 8: e3218.

WHO. 2017. Integrating neglected tropical diseases into global health and development. Fourth WHO report on neglected tropical diseases. Geneva, Switzerland. Licence: CC BY-NC-SA 3.0 IGO.

WHO. 2018. Neglected tropical diseases. http://www.who.int/ neglected_diseases/en/. Accessed 12 July 2018.

Yu, K-X., I. Jantan, R. Ahmad and C-L. Wong. 2014. The major bioactive components of seaweeds and their mosquitocidal potential. Parasitol. Res. 113: 3121-3141.

Zhou, G.F., Y. Sun, H. Xin, Y. Zhang, Z. Li and Z. Xu. 2005. In vivo antitumor and immunomodulation activities of different molecular weight lambda-carrageenans from Chondrus ocellatus. Pharmacol. Res. 50: 47-53.

Article note: This article is part of the special issue series of Botanica Marina: Seaweed resources of the world: a 2020 vision, starting publication in Botanica Marina 2019, vol. 62, issue 3. The series will be guest-edited by Alan T. Critchley, Anicia Hurtado, Leonel Pereira, Melania Cornish, Danilo Largo and Nicholas Paul.

\section{Bionotes}

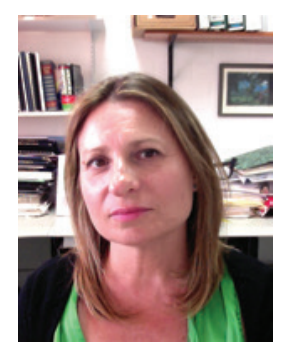

\section{Yolanda Freile-Pelegrín}

Department of Marine Resources, CinvestavUnidad Merida, 97310, A.P.73 Cordemex, Merida, Yucatan, Mexico, yolanda.freile@cinvestav.mx

Yolanda Freile-Pelegrín is a full researcher at Centro de Investigación y Estudios Avanzados del Instituto Politécnico Nacional (CINVESTAV), Mérida, Mexico. She obtained her BSc and Dr.Sc in Marine Sciences from Universidad de Las Palmas Spain (ULPGC). Her interest includes seaweed chemistry, physiology, ecology and applied phycology.

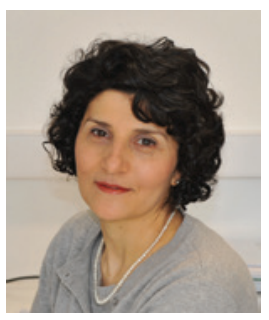

Deniz Tasdemir GEOMAR Centre for Marine Biotechnology (GEOMAR-Biotech), Marine Natural Products Chemistry Research Unit, GEOMAR Helmholtz Centre for Ocean Research Kiel, Am Kiel Kanal 44, 24106 Kiel, Germany and; Kiel University, Christian-Albrechts-Platz 4, Kiel 24118, Germany

Deniz Tasdemir is a full professor of marine natural products chemistry at GEOMAR Helmholtz Centre for Ocean Research Kiel (Germany). She obtained her PhD degree at ETH-Zurich (Switzerland) and a post-doctoral training at University of Utah (USA). She was a senior lecturer at University of London and a full professor at National University of Ireland Galway. Her research focus is discovery of anti-infectious/anticancer marine molecules. 